\title{
Selective feeding of Acartia clausi and Centropages typicus on microzooplankton*
}

\author{
Ngurah N. Wiadnyana, Fereidoun Rassoulzadegan
}

Station Zoologique (UA 716), BP 28, F-06230 Villefranche-sur-Mer, France

\begin{abstract}
Selective feeding of 2 common copepods, Acartia clausi and Centropages typicus, on mixtures of ciliates and planktonic algae was investigated. Results show the ability of these copepods to recognize the quality of their particulate foods. An equiproportional mixture (in terms of biovolume) of the oligotrichous ciliate Strombidium sulcatum and either the dinoflagellate Prorocentrum micans or the diatom Thalassiosira weissflogii was offered to the copepods. The copepods ingested ciliates, at rates of $3.2 \times 10^{5} \mu^{3}$ copepod $^{-1} \mathrm{~h}^{-1}$ for A. clausi and $4.3 \times 10^{5} \mu^{3}$ copepod $^{-1} \mathrm{~h}^{-1}$ for C. typicus (67 and $80 \%$ of the total ingested ration respectively), when ciliate + dinoflagellate mixtures were offered. A. clausi preferred S. sulcatum to $T$ weissflogii, and ingested the ciliate at a rate of $3.7 \times 10^{5} \mu \mathrm{m}^{3}$ copepod $\mathrm{d}^{-1} \mathrm{~h}^{-1}$ ( $75 \%$ of total ingested ration). The differences observed in the selection of 2 types of prey by copepods were reflected in a positive Ivlev Electivity Index for the ciliates (as high as +0.73 ) and in a negative Index for both dinoflagellates and diatoms (as low as -1.00). Ecological implications of this type of selective feeding behaviour in mesozooplankton are also discussed.
\end{abstract}

\section{INTRODUCTION}

In the past, studies of selective feeding in planktonic copepods have mainly dealt with different planktonic algal diets (Mullin \& Brooks 1967, Paffenhöfer \& Knowles 1978, Frost 1980, Paffenhöfer 1984). Copepods seem to graze more efficiently on the relatively large (microplankton) and more abundant particles (Harvey 1937. Mullin 1963, Frost 1972, Gaudy 1974, Poulet 1974. Nival \& Nival 1976, Donaghay \& Small 1979, Paffenhöfer \& Knowles 1980). In their recent review, Sherr et al. (1986) posed the question: "whether the "microbial loop", involving microbial producers and their protozoan grazers, is a source of biomass to food chains leading up to nekton, or whether this part of the food web is mostly a shunt of organic carbon from the ecosystem and is important only in terms of regeneration of mineral nutrients'.

Carnivory in young and adult copepods has already been shown (Petipa et al. 1970, Landry 1978, Lonsdale et al. 1979, Paffenhöfer \& Knowles 1980). More recent studies have clearly demonstrated predation by metazooplankton on ciliates (Berk et al. 1977, Porter et al. 1979, Robertson 1983, Stoecker \& Sanders 1985,

\footnotetext{
- Contribution of the team Ecologie du Microzooplancton Marin'
}

Sheldon et al. 1986). Although Heinle et al. (1977) have shown that copepods can consume ciliates at rates comparable to those on algal foods, there is virtually no documentation on the comparative feeding behaviour of copepods when phototrophic and heterotrophic food particles are equally available. In an earlier microcosm study, we observed a preference of the copepod Euterpina acutifrons for an oligotrich ciliate, Lohmanniella spiralis, to either diatoms or phytoflagellates coexisting in the same system (Sheldon et al. 1986). This observation stimulated us to make, for the first time, a more comprehensive investigation of selective feeding by copepods on ciliates.

In the present work, we compared feeding behaviours of 2 common copepods, Acartia clausi and Centropages typicus, when exposed to a mixture of naked oligotrich ciliates and algae, of comparable size, and present in equal biovolume.

\section{MATERIAL AND METHODS}

Both copepods, Acartia clausi Giesbrecht and Centropages typicus Kroyer, were collected with a WP II zooplankton net and a 'Homogeneous Plankton Net' ( $0.20 \mathrm{~mm}$ and $0.28 \mathrm{~mm}$ mesh size respectively) at Point $B$, a standard oceanographic station at the mouth of the Bay 
of Villefranche, France $\left(43^{\circ} 41^{\prime} 10^{\prime \prime} N, 7^{\circ} 19^{\prime} 0^{\prime \prime}\right.$ E). Samples were immediately transferred to the laboratory, and adults of both sexes were gently isolated and transferred to $250 \mathrm{ml}$ glass vessels containing seawater filtered through $0.45 \mu \mathrm{m}$ Millipore membrane filters. The copepods were subsequently acclimated for 24 h at $20^{\circ} \mathrm{C}$.

Three food sources were examined: the oligotrich ciliate Strombidium sulcatum Claparède \& Lachmann, the dinoflagellate Prorocentrum micans Ehrenberg, and the diatom Thalassiosira weissflogii Actin. The ciliate cultures were prepared according to Rivier et al. (1985), whereas the 2 algae species were obtained in seawater enriched with F/2 Guillard medium. They were offered to the copepods at their exponential growth stages.

After the acclimation period, the copepods were placed in 21 glass bottles ( 3 replicates), containing 0.45 $\mu \mathrm{m}$ Millipore membrane filtered seawater, at final concentrations of 5 copepods $1^{-1}$, comparable with in situ levels in our waters. Comparability with natural conditions was also maintained for food concentrations (in situ ranges: $10^{3}$ to $10^{4}$ ciliates $1^{-1}, 4.5 \times 10^{2}$ to $12 \times 10^{3}$ dinoflagellates $1^{-1}$, and $2 \times 10^{2}$ to $10^{6}$ diatoms $\mathrm{l}^{-1}$, according to Rassoulzadegan \& Gostan 1976, and Rassoulzadegan 1979). To obtain food biomass-equivalent mixtures the following additions were made per liter: $3.3 \times 10^{3}$ ciliates (biovolume $=13.9 \times 10^{3} \mu^{3} \mathrm{cell}^{-1}$ ) and $5.0 \times 10^{3}$ dinoflagellates (biovolume $=8.8 \times 10^{3}$ $\mu \mathrm{m}^{3}$ cell $^{-1}$ ), or $4.6 \times 10^{3}$ ciliates and $4.5 \times 10^{4}$ diatoms (average biovolume $=1.6 \times 10^{3} \mathrm{\mu m}^{3} \mathrm{cell}^{-1}$ ). In order to sustain the ciliates during the copepod grazing experiments, planktonic bacteria were added to the bottles to a final concentration of ca $6 \times 10^{5}$ bacteria $\mathrm{ml}^{-1}$. This concentration has previously been shown to represent a threshold value for growth of a pre-starved strain of Strombidium sulcatum (Wiadnyana \& Rassoulzadegan unpubl.), such as that we used here for our experiments.

Following the above procedure, food preference in Acartia clausi was studied in 4 feeding experiments, 2 experiments with a mixture of dinoflagellates and ciliates (June to September 1987), and 2 with a mixture of diatoms and ciliates (January and February 1988). Selective feeding in Centropages typicus was studied in only 2 experiments (June 1987) where a mixture of dinoflagellates and ciliates was offered. These are outlined in Table 1.

These feeding experiments were conducted in incubation bottles rotating at $12 \mathrm{rpm}$ using a Fenaux \& Gorsky (1979) grazing wheel, at 18 to $22^{\circ} \mathrm{C}$. The experiments were run over $18 \mathrm{~h}$. Samples of $50 \mathrm{ml}$ were taken at the beginning and at every $2 \mathrm{~h}$ interval, and fixed with Lugol solution (Throndsen 1978). The ciliates and algae were counted in each sample by the Utermöhl method. An average of 30 ciliates was considered to work within of the Poisson distribution law (Rassoulzadegan \& Gostan 1976).

Ingestion rates were determined by using Frost's grazing equation (Frost 1972). Selective feeding was investigated using 2 approaches. The first was to follow the changes in the prey biomass ratios (ciliate/algal food), during the feeding experiments (the initial ratio was about 1). The biomass ratios were calculated from the mean of the 3 replicates (Table 1). The second approach was to compare the Ivlev's Electivity Index (Ivlev 1961) between the 2 prey at each sampling time interval during the copepod feeding experiments. This index (E) was calculated from the means of the 3 replicates (Table 1 ).

\section{RESULTS}

Table 1 shows the time-series changes in prey concentrations in the mixtures during the feeding experiments with Acartia clausi $(A, B=$ ciliates + dinoflagellates; $C, D=$ ciliates + diatoms), and with Centropages typicus $(\mathrm{E}, \mathrm{F}=$ ciliates + dinoflagellates). The data were used for the copepod grazing rate calculations. These estimates suggest that when the ciliate + dinoflagellate mixtures were offered, $A$. clausi ingested ciliates at rates varying between $1.1 \times 10^{4} \mu \mathrm{m}^{3}(0.88$ cells) and $8.8 \times 10^{5} \mu^{3}$ (63.53 cells) copepod ${ }^{-1} \mathrm{~h}^{-1}$, and dinoflagellates at rates from 0 to $4.9 \times 10^{5} \mu \mathrm{m}^{3}$ (56.58 cells) copepod ${ }^{-1} \mathrm{~h}^{-1}$. When food mixtures containing ciliates and diatoms were offered, feeding rates varied from $5.0 \times 10^{4} \mu^{3}$ (3.57 cells) to $1.1 \times 10^{6} \mu^{3}$ ( 79.14 cells) copepod ${ }^{-1} \mathrm{~h}^{-1}$ for ciliates, and from 0 to 8.9 $\times 10^{5} \mu^{3}$ (481.08 cells) copepod ${ }^{-1} \mathrm{~h}^{-1}$ for diatoms, respectively. In the case of $C$. typicus, where only the ciliate + dinoflagellate mixtures were used, the copepod removed ciliates at rates from $6.1 \times 10^{4} \mu^{3}$ (4.37 cells) to $2.2 \times 10^{6} \mu^{3}$ (160.65 cells) copepod ${ }^{-1}$ $\mathrm{h}^{-1}$, and dinoflagellates at rates from 0 to $5.3 \times 10^{5} \mathrm{um}^{3}$ ( 60.00 cells) copepod ${ }^{-1} \mathrm{~h}^{-1}$. For both copepods studied, the ciliate consumption rates seem to be always maximal at the beginning of the feeding experiments (Fig. 1), when the biomass of both ciliate and algal prey were almost equal in the mixtures. Feeding rates on dinoflagellates and/or diatoms were more variable than on ciliates, especially in experiments where the mixture contained dinoflagellates (Figs. 1 and 2).

These data show that, whether the mixtures contained ciliates/dinoflagellates or ciliates/diatoms, the copepod's estimated ration was dominated by ciliates (78.1 to $100 \%$ in the ciliate + dinoflagellate mixtures, and 55.5 to $100 \%$ in the ciliate + diatom mixtures). This is especially evident when the ciliate/algal ratio $=1$, near the beginning of the incubations.

The estimated clearance rates of Acartia clausion cili- 


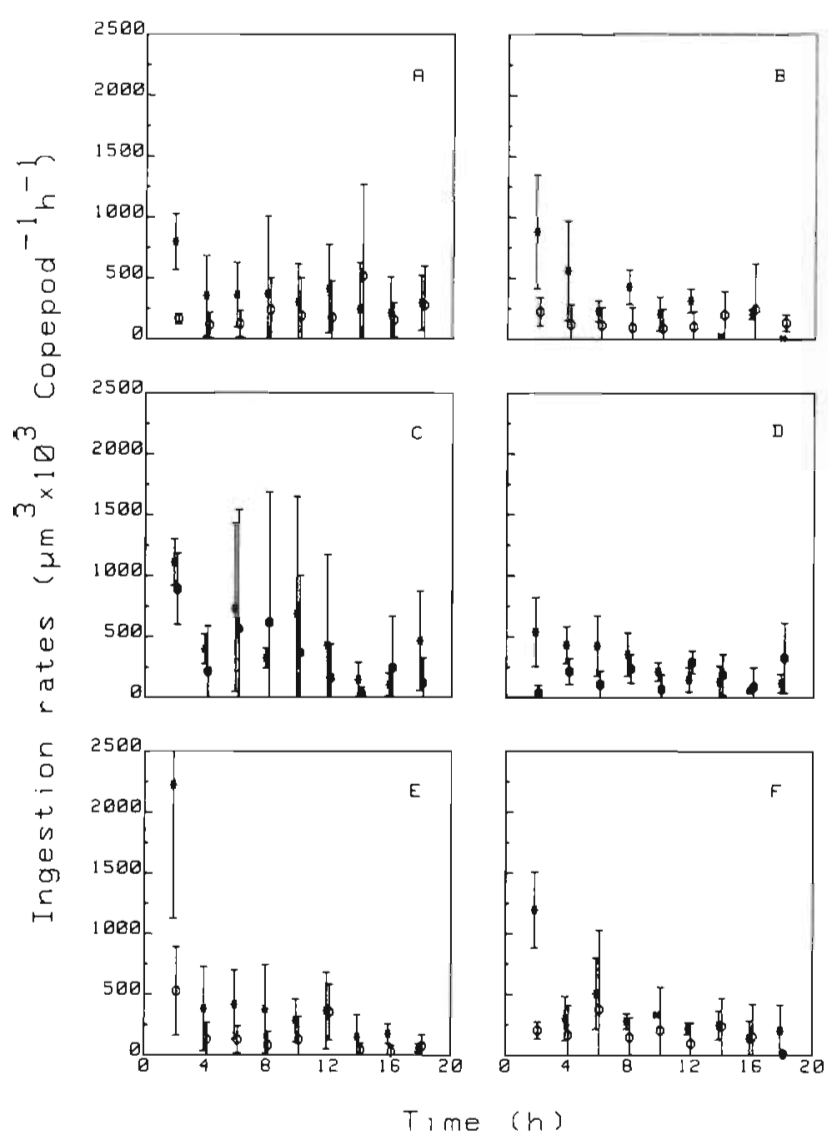

Fig. 1. Ingestion rates of copepods. A, B and C, D: Acartia clausi exposed to ciliate + dinoflagellate and ciliate + diatom mixtures; E, F: Centropages typicus exposed to ciliate + dinoflagellate mixtures. Means \pm SD for $(*)$ ciliates, $(0)$ dinoflagel-

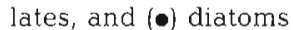

ates varied between 1.43 and $26.26 \mathrm{ml} \mathrm{copepod}^{-1} \mathrm{~h}^{-1}$ in the mixtures containing dinoflagellates and varied between 1.58 and $16.07 \mathrm{ml}$ copepod $^{-1} \mathrm{~h}^{-1}$ in the mixture containing diatoms. The clearance rates on dinoflagellates and on diatoms varied between 0 and 12.96 $\mathrm{ml}$ copepod ${ }^{-1} \mathrm{~h}^{-1}$, and between 0 and $12.54 \mathrm{ml}$ copepod ${ }^{-1} \mathrm{~h}^{-1}$, respectively (Fig. 2). In Centropages typicus, clearance rates varied between 5.36 and 58.08 $\mathrm{ml}$ copepod $^{-1} \mathrm{~h}^{-1}$ for the ciliates, and between 0 and 12.34 ml copepod $\mathrm{d}^{-1} \mathrm{~h}^{-1}$ for the dinoflagellates (Fig. 2).

Fig. 3 shows the time-series changes in ciliate/algae ratios for the different copepod feeding experiments. It is seen that the ratios usually decrease gradually from the beginning towards the end of each experiment, but in some experiments seem to tend towards a plateau during the last $8 \mathrm{~h}$.

This preference for ciliates is reflected in the timeseries changes in the Ivlev's Electivity Index values, calculated for each type of food at each time interval (Fig. 4). The Electivity Index values for ciliates are less variable than for the flagellates and/or diatoms and the

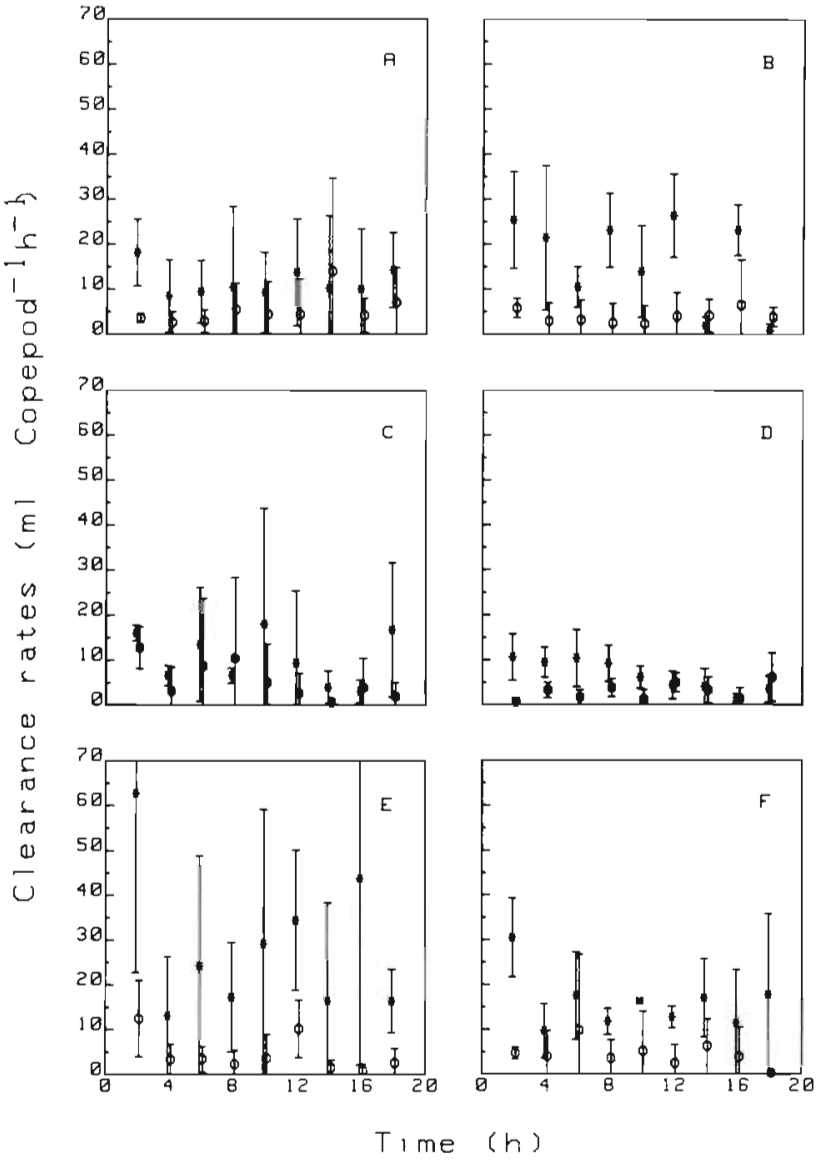

Fig. 2. Clearance rates of copepods. A, B and C, D: Acartia clausi exposed to ciliate + dinoflagellate and ciliate + diatom mixtures; E, F: Centropages typicus exposed to ciliate + dinoflagellate mixtures. Means \pm SD for $(*)$ ciliates, $(0)$ dinoflagellates, and $(\bullet)$ diatoms

absolute index value for ciliates is usually positive, but there appears to be a tendency for the index to reverse at about the 12 th hour of experimentation, when the ciliate concentration had become very low (Table 1).

\section{DISCUSSION}

It has been known for a long time that many copepods previously considered phytophagous can in fact be carnivorous and/or omnivorous (see Sherr et al. 1986 for review). Recent evidence indicates that ciliates can be a food source for mesozooplankton (Berk et al. 1977, Porter et al. 1979, Robertson 1983, Stoecker \& Sanders 1985, Gifford 1986, Sheldon et al. 1986, Ayukai 1987, Gifford \& Dagg 1987, Stoecker \& Egloff 1987, Stoecker et al, 1987). Heinle et al. (1977) showed that ciliates as well as phytoplankton could be food sources for copepods. Studies on the utilization of microzooplankton by copepods are rare. Based on recent 


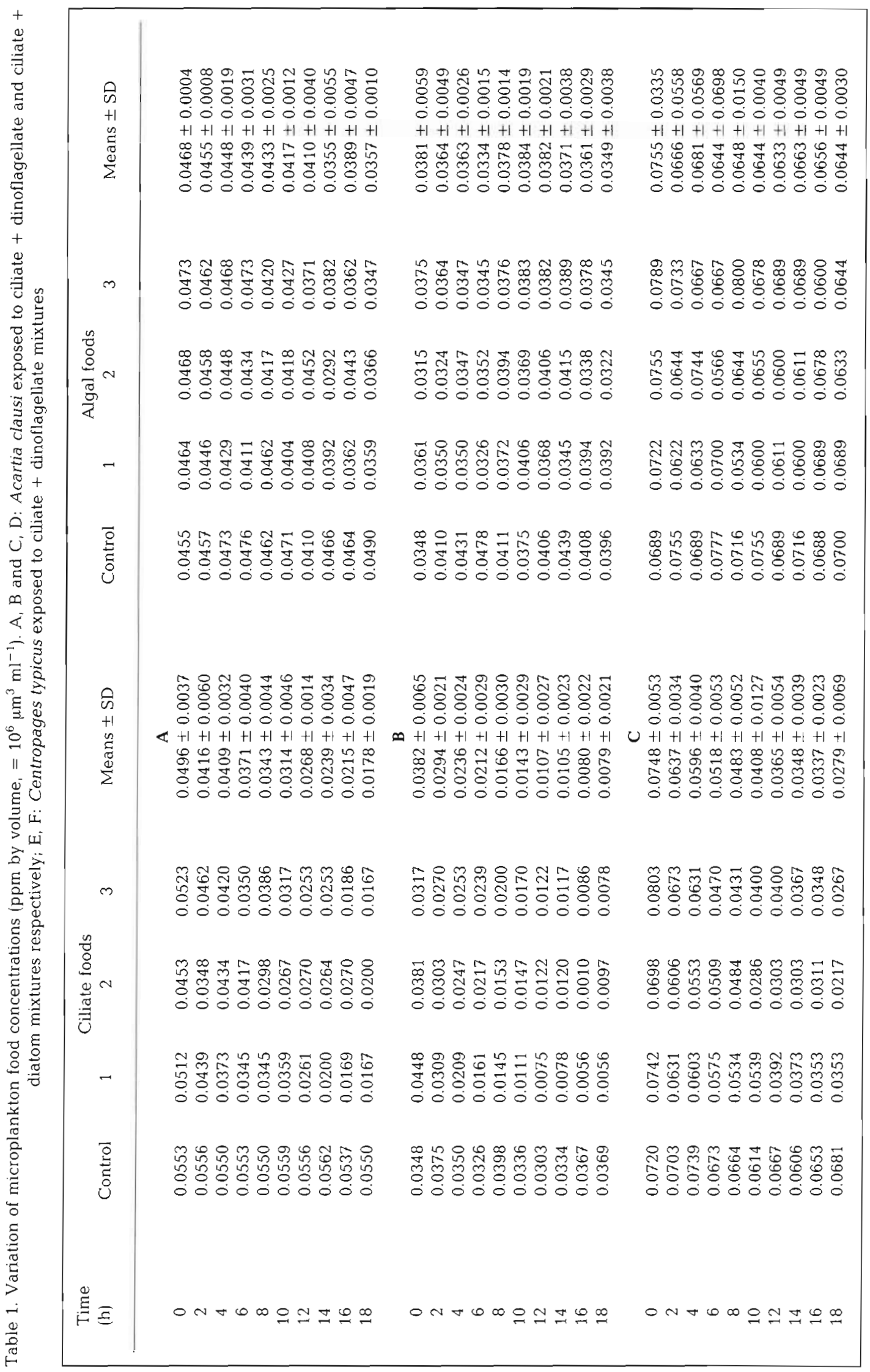




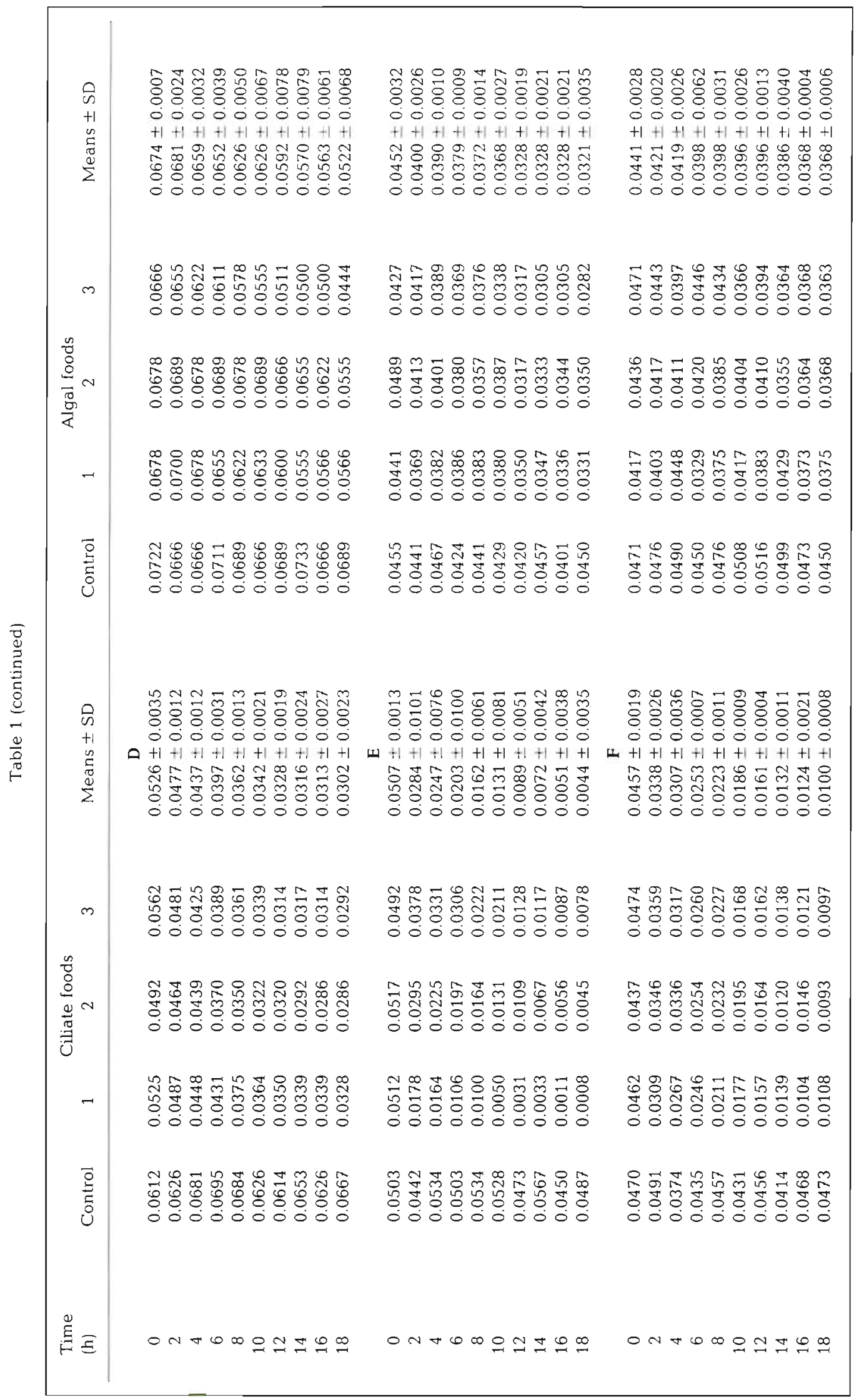




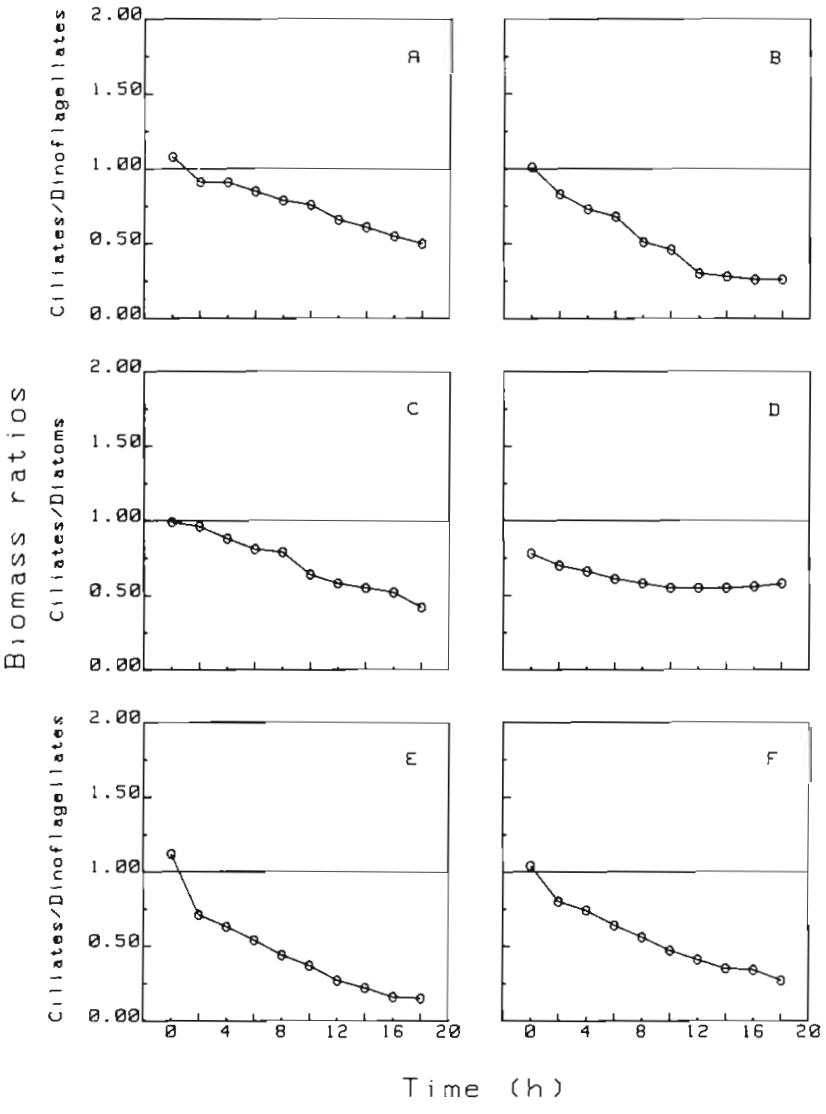

Fig. 3. Variation of ciliate/algae biovolume ratios, calculated from the mean of the 3 replicates reported in Table 1. A, B and C, D: Acartia clausi exposed to ciliate + dinoflagellate and ciliate + diatom mixtures; E, F: Centropages typicus exposed to ciliate + dinoflagellate mixtures

observations of the preference of copepods for planktonic ciliates in natural populations (Sheldon et al. 1986) and in laboratory experiments (Turner \& Anderson 1983, Stoecker \& Sanders 1985, Ayukai 1987), we decided to investigate this phenomenon in detail. In our experiments, we: (1) offered the copepods animal and algal food simultanously (as done by Turner \& Anderson 1983, Stoecker \& Sanders 1985, and Stoecker \& Egloff 1987); (2) used representatives of natural plankton as food particles; (3) chose ciliate and algal prey of approximately similar size; this has not been considered in previous literature, but seems to be a crucial factor in this kind of investigation (Lonsdale et al. 1979); (4) offered equal volumes (biomass) of prey species, which has not been done in earlier copepod/ ciliate selective feeding experiments; and (5) used aloricate ciliates as a representative major microzooplankton (Stoecker \& Egloff 1987).

We initially chose the planktonic oligotrich ciliate Strombidium sulcatum as the animal food, and the dinoflagellate Prorocentrum micans $(1 \mathrm{~S}$. sulcatum $=$

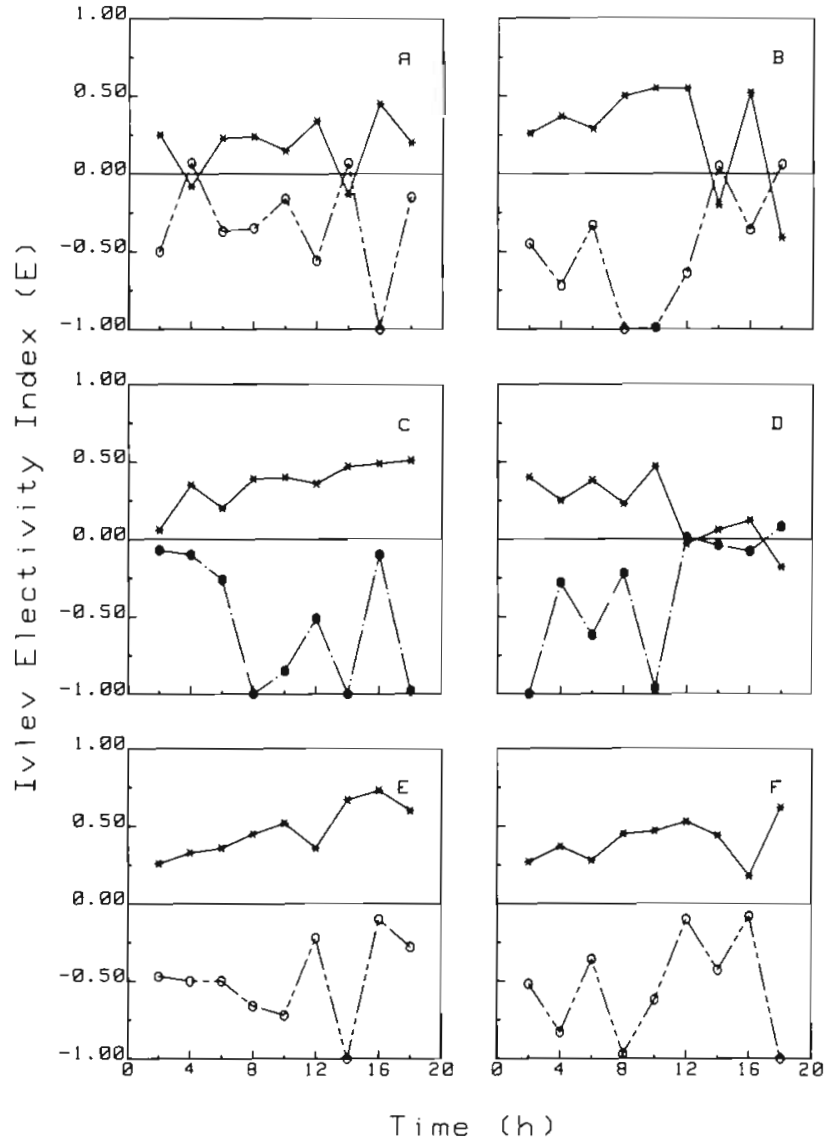

Fig. 4. Fluctuation of Ivlev Electivity Index (E). A, B and C, D: Acartia clausi exposed to ciliate + dinoflagellate and ciliate + diatom mixtures; E, F: Centropages typicus exposed to ciliate + dinoflagellate mixtures. (*) ciliates, $(0)$ dinoflagellates, (•) diatoms

1.56 P. micans in cell volume) as the algal prey for these experiments. Gill \& Harris (1987) found that compared to diatoms, dinoflagellates (except for $P$. micans) are not a preferred food of copepods. Their results support earlier observations on the inhibition of copepod feeding by dinoflagellates and on the differences between the feeding rates of copepods on dinoflagellates and diatoms (Conover 1978, 1980, Fiedler 1982, Huntley 1982). Although the dinoflagellate $P$. micans seems to be a good food source for copepods, we decided to conduct additional experiments in which the dinoflagellates were replaced by the diatom Thalassiosira weissflogii as the algal food in the mixtures. This diatom has already been used in similar experiments (Anraku \& Omori 1963). We found that the copepods selected ciliates over diatoms as well as over dinoflagellates. This is in agreement with work by Paffenhöfer \& Knowles (1980), who found that predation by adult copepods on copepod nauplii was not affected by the presence of diatoms. In our experi- 
ments, Acartia clausi ingested an average of 599 ciliates copepod $\mathrm{d}^{-1} \mathrm{~d}^{-1}$ and Centropages typicus ingested an average 744 ciliates copepod ${ }^{-1} \mathrm{~d}^{-1}$. About 66 to $89 \%$ of the copepods' ration, in the presence of either diatoms or dinoflagellates, was accounted for by feeding on ciliates. These results are comparable with the few data available in the literature. Berk et al. (1977) found that the copepod Eurytemora affinis can ingest the ciliate Uronema nigricans (cell volume about 20 times smaller than that of the oligotrichs studied here) at rates from 700 to 5700 ciliates copepod ${ }^{-1} \mathrm{~d}^{-1}$. For Acartia tonsa, Stoecker \& Sanders (1985) found rates of around 120 ciliates Favella sp. (in biovolume, 14 times larger than our ciliate) copepod ${ }^{-1} \mathrm{~d}^{-1}$

The preference of copepods for ciliates seems to be related to the existence of mechanoreception in copepods, which detect moving prey (G.-A. Paffenhöfer pers. comm.). Moreover, copepods may grow on ciliates with an efficiency of $32 \%$ (Sheldon et al. 1986), and the egg production of copepods feeding on ciliates is significantly higher than that of copepods feeding on algae (Stoecker \& Egloff 1987).

Our results show that at the beginning of the feeding experiments, when biomass of animal and algal food sources were about equal, the copepods exhibited maximum feeding rates on ciliates, whereas their feeding rates on the flagellate and/or diatom were variable through the incubation. This selective feeding behaviour modified the protozoan/algal biomass ratios during the experiment. The patterns in some experiments suggest the possibility of 'opportunistical switching' of copepod feeding. This finding supports the hypothesis that copepod predation can significantly influence ciliate production in nature (Smetacek 1981 , Stoecker \& Sanders 1985).

Stoecker \& Sanders (1985) discussed how 'ciliates/ dinoflagellates-copepod' feedback may regulate plankton populations in Perch Pond, Falmouth, Massachusetts, USA. We would add here another aspect of the ciliate/copepod interaction which is of ecological interest in pelagic ecosystems. The reasons for choosing the aloricate ciliate Strombidium sulcatum in our feeding experiments were that: (1) aloricate ciliates dominate the microzooplankton (Beers \& Stewart 1967), and (2) they are able to feed on planktonic bacteria (Lessard \& Swift 1985, Rivier et al. 1985 , Sherr \& Sherr 1987), picophytoplankton (Lessard \& Swift 1985, Rassoulzadegan et al. 1988), 'pico-sized' particles (Børsheim 1984), flagellates (Rassoulzadegan 1982, Sheldon et al. 1986) and 'nano-sized' particles (Fenchel 1980, Rassoulzadegan \& Etienne 1981). The relatively recent discoveries show: (1) the importance of both hetero- and autotrophic planktonic bacteria as a significant part of pelagical particle production (Azam \& Hodson 1977, Platt et al. 1983), and (2) the existence of tight coupling between bacteria and heterotrophic microprotozoa (Sieburth 1979, Ducklow 1983, Furhman \& McManus 1984, Sieburth 1985, Rassoulzadegan \& Sheldon 1986, Caron et al. 1988) leading to a microbial loop' (ML) as proposed by Azam et al. (1983).

In the absence of the appropriate grazers $(\geq 10 \mu \mathrm{m}$ protozooplankton) on heterotrophic flagellates, the $\mathrm{ML}$ would behave predominantly rather as a sink for the organic carbon web because most copepods are unable to directly consume cells $<2$ to $5 \mu \mathrm{m}$ (Nival \& Nival 1976). This was probably the case in the study by Ducklow et al. (1986), who found virtually no transfer of microbial production to higher trophic levels (HTL). Microzooplankton are probably a necessary link for moving production from the ML, or the microbial food webs (MFW) in general, into HTL. Furthermore, as we have shown here, there is a preference of the larger zooplankton for the planktonic ciliates. The small aloricate planktonic ciliates can interact then as the HTL's 'Trojan horse', making production in the 'closed ML' available to larger zooplankton. This observation supports Conover (1981), who considered that the copepod consumption of the microzooplankton 'facilitates efficient entry of the smallest producing particles, the $\mu$ flagellates, into the food web'. This subsequently reduces 'the amount of energy that goes to the decomposer side'.

In a more general context, the trophic status for the ML or the MFW in general still remains controversial (Ducklow et al. 1986, Sherr et al. 1987). However with respect to the definition of the food 'link' or 'sink' role for the MFW, there is need for a clarification of terms. The 'sink' hypothesis seems generally to use the argument that the metazooplankton utilize only a small percent of the bacterioplanktonic net production (Ducklow et al. 1986). Indeed there is good evidence that the microbial planktonic production is mainly recycling, rather than being massively transferred to HTL. Nevertheless the argument for the 'sink' hypothesis is weak since it fails to take account of the following facts: (1) there are $\geq 3$ trophic steps between bacteria and copepods (Goldman \& Caron 1985, Rassoulzadegan \& Sheldon 1986, Pomeroy \& Wiebe 1988), and (2) microprotozoa have specific nutrient regeneration rates higher than those reported for metazoa (Goldman et al. 1985). In addition, with respect to dependence of the energy transfer on the number of the trophic steps, the efficiency of the food web segment including levels from bacteria to copepods would be at least comparable to that of the segment covering steps from diatoms to macrophagous fishs. However, unlike bacteria, diatoms are customarily considered as a significant food link in the pelagic ecosystems.

Pomeroy \& Wiebe (1988) consider that 6 or $12 \%$ of the microbial food web's energy can be transferred to 
HTL via 4 or 3 trophic steps, respectively. In our waters we found that when cyanobacteria are the dominant primary producer, $>80 \%$ of primary production is balanced by respiration due to heterotrophic bacteria and microprotozoa, leaving $6 \%$ of this production to HTL (Hagström et al. 1988). An average of $10 \%$ of the microbial net production is approximately what would normally be expected to reach HTL in the traditional food web via 'food-link' pathways. This is a relatively small number, but a significant amount in absolute terms, considering that the MFW 'traps' $\geq 50 \%$ of the total primary production (Platt et al. 1983), and is responsible for $>90 \%$ of the water column's total heterotrophic activity (Pomeroy 1974, Azam \& Hodson 1977). However, the transfer would be almost interrupted without the $\geq 10 \mu \mathrm{m}$ protozooplankton. According to the data of Hagström et al. (1988), for instance, almost nothing would ascend to HTL.

We conclude therefore that the marine microbial community should not be considered solely as a food 'sink', but as both a crucial food web segment and an important source of nutrient recycling in the pelagial.

Acknowledgements. We thank Gustav Paffenhöfer, Roger Harris, Diane Stoecker, and the anonymous reviewers for their constructive comments and advice. $M$. Etienne helped the data computation. As a part of N.N.W.'s Ph. D., this research was supported by CNRS/INSU, FMO-DYFAMED, UA 716, and an Indonesian Government Fellowship to N.N.W.

\section{LITERATURE CITED}

Anraku, M. Omori, M. (1963). Preliminary survey of the relationship between the feeding habit and the structure of the mouth-parts of marine copepods. Limnol. Oceanogr. 8: $116-126$

Ayukai, T. (1987). Predation by Acartia clausi (Copepoda: Calanoida) on two species of tintinnids. Mar. Microb. Food Webs 2 (1): 45-52

Azam, F. Hodson, R. E. (1977). Size distribution and activity of marine microheterotrophs. Limnol. Oceanogr. 22: 492-501

Azam, F., Fenchel, T., Field, J. G., Gray, L.-A., Meyer-Reil, L. A., Thingstad, F. (1983). The ecological role of water col. umn microbes in the sea. Mar. Ecol. Prog. Ser. 10: 257-263

Beers, J. R., Stewart, G. L. (1967). Micro-zooplankton in the euphotic zone at five locations across the California Current. J. Fish. Res. Bd Can. 24: 2053-2068

Berk, S. G., Brownlee, D. C., Heinle, D. R., Kling, H. J., Colwell, R. R. (1977). Ciliates as a food source for marine planktonic copepods. Microb. Ecol. 4: $27-40$

Børsheim, K. Y. (1984). Clearance rates of bacteria-sized particles by freshwater ciliates, measured with mono-disperse fluorescent latex beads. Oecologia (Berl.) 63: 286-288

Caron, D. A., Goldman, J. C., Dennett, M. R. (1988). Experimental demonstration of the roles of bacteria and bacterivorous protozoa in plankton nutrient cycles. Hydrobiologia 159: $27-40$

Conover, R. J. (1978). Feeding interactions in the pelagic zone. In: Parsons, T. R., Jansson, B. O., Longhurst, A. R., Soeters- dal, G. (eds.) Marine ecosystem and fisheries oceanography. Rapp. P.-v. Réun. Cons. int. Explor. Mer 173: 66-76

Conover, R. J. (1980). General rules of grazing in pelagic ecosystems. In: Falkowski, P. G. (ed.) Primary productivity in the sea. Plenum Press, New York, p. 461-485

Conover, R. J. (1981). Nutritional strategies for feeding on small suspended particles. In: Longhurst, A. R. (ed.) Analysis of marine ecosystems. Academic Press, New York, p. 363-395

Donaghay, P. L., Small, L. F. (1979). Food selection capabilities of the estuarine copepod Acartia clausi. Mar. Biol. 52: $137-146$

Ducklow, H. W. (1983). The production and fate of bacteria in the ocean. BioScience 33: 494-501

Ducklow, H. W., Williams, P. J. LeB, Davies, J. M. (1986). Bacterioplankton: a sink for carbon in coastal marine plankton community. Science 232: 865-867

Fenaux, R., Gorsky, G. (1979). Techniques d'élevage des appendiculaires. Ann. Inst. océanogr., Paris 52 (2): 195-200

Fenchel, T. (1980). Suspension feeding in ciliated protozoa: feeding rates and their ecological significance. Microb. Ecol. 6: 13-25

Fiedler, P. C. (1982). Zooplankton avoidance and reduced grazing responses to Gymnodinium splendens (Dinophyceae). Limnol. Oceanogr. 27: 961-965

Frost, B. W. (1972). Effects of size and concentration of food particles on the feeding behavior of the marine planktonic copepod Calanus pacificus. Limnol. Oceanogr. 17 (6): 805-815

Frost, B. W. (1980). Grazing. In: Morris, I. (ed.) The physiological ecology of phytoplankton. Studies in ecology, Vol. 7. Univ. Calif. Press, Los Angeles, p. 465-491

Fuhrman, J. A., McManus, G. B. (1984). Do bacteria-sized marine eukaryotes consume significant bacterial production? Science 224: 1257-1260

Gaudy, R. (1974). Feeding four species of pelagic copepods under experimental conditions. Mar. Biol. 25: 125-141

Gifford, D. J. (1986). Grazing on natural microzooplankton assemblages by the copepod Acartia tonsa. [Abstract.] EOS 67: 967

Gifford, D. J., Dagg, M. J. (1987). Consumption of ciliate microzooplankton by Neocalanus plumchrus in the subarctic North Pacific Ocean. [Abstract.] EOS 68: 1705

Gill, C. W., Harris, R. P. (1987). Behavioural responses of the copepods Calanus helgolandicus and Temora longicornis to dinoflagellate diets. J. mar, biol. Ass. U. K. 67: 785-801

Goldman, J. C., Caron, D. A. (1985). Experimental studies on an omnivorous microflagellate. Implication for grazing and nutrient regeneration in the marine microbial food chain. Deep Sea Res. 32 (8A): 899-915

Goldman, J. C., Caron, D. A., Andersen, O. K., Dennett, M. R. (1985). Nutrient cycling in a microflagellate food chain. I. Nitrogen dynamics. Mar. Ecol. Prog. Ser. 24: 231-242

Hagström, §., Azam, F., Andersson, A., Wikner, J., Rassoulzadegan. F. (1988). Microbial loop in an oligotrophic pelagic marine ecosystem: possible roles of cyanobacteria and nanoflagellates in the organic fluxes. Mar. Ecol. Prog. Ser. 49: $171-178$

Harvey, H. W (1937). Note on selective feeding by Calanus. J. mar biol. Ass. U. K. 22: 97-100

Heinle, D. R., Harris, R. P., Ustach, J. F., Flemer, D. A. (1977) Detritus as food for estuarine copepods. Mar Biol. 40 341-353

Huntley, M. E. (1982). Yellow water in La Jolla Bay, California, July 1980. II. Suppression of zooplankton grazing J. exp. mar. Biol. Ecol. 63: 81-91 
Ivlev, $V$ S. (1961). Experimental ecology of the feeding of fishes. (Translated by D. Scott). Yale University Press, New Haven

Landry, M. R. (1978). Population dynamics and production of a planktonic marine copepod, Acartia clausi, in a small temperate lagoon on San Juan Island, Washington. Int. Revue ges. Hydrobiol. 63: 77-119

Lessard, E. J., Swift, E. (1985). Species-specific grazing rates of heterotrophic dinoflagellates in oceanic waters, measured with a dual-label radioisotope technique. Mar Biol. 87: $289-296$

Lonsdale, D. J., Heinle, D. R., Siegfried, C. (1979). Carnivorous feeding behavior of the adult calanoid copepod Acartia tonsa Dana. J. exp. mar. Biol. Ecol. 36: 235-248

Mullin, M. M. (1963). Some factors affecting the feeding of marine copepods of the genus Calanus. Limnol. Oceanogr. 8: $239-250$

Mullin, M. M., Brooks, E. R. (1967). Laboratory culture, growth rate, and feeding behavior of a planktonic marine copepod. Limnol. Oceanogr. 12: 47-58

Nival, P., Nival, S. (1976). Particle retention efficiencies of an herbivorous copepod, Acartia clausi (adult and copepodite stages): effects on grazing. Limnol. Oceanogr. 21 (1): $25-49$

Paffenhöfer, G.-A. (1984). Food ingestion by the marine planktonic copepod Paracalanus in relation to abundance and size distribution of food. Mar. Biol. 80: 323-333

Paffenhöfer, G.-A., Knowles, S. C. (1978). Feeding of marine planktonic copepods on mixed phytoplankton. Mar. Biol. 48: 143-152

Paffenhöfer, G.-A., Knowles, S. C. (1980). Omnivorousness in marine planktonic copepods. J. Plankton Res. 2: 355-365

Petipa, T. S., Pavlova, E. V., Mironov, G. N. (1970). The food web structure, utilization and transport of energy by trophic levels in the planktonic communities. In: Steele, J. $\mathrm{H}$. (ed.) Marine food chains. Oliver and Boyd Press, Edinburgh, p. $142-167$

Platt, T., Subba Rao, D. V., Irwin, B. (1983). Photosynthesis of picoplankton in the oligotrophic ocean. Nature, Lond. 310 : $702-704$

Pomeroy, L. R. (1974). The ocean's food web, a changing paradigm. BioScience 24: 499-504

Pomeroy, L. R., Wiebe, W. J. (1988). Energetics of microbial food webs. Hydrobiologia 159: 7-18

Porter, K. G, Pace, M. L., Battey, J. F. (1979). Ciliate protozoans as links in freshwater planktonic food chains. Nature, Lond. 277: 563-565

Poulet, S. A. (1974). Seasonal grazing of Pseudocalanus minutus on particles. Mar. Biol. 25: 109-123

Rassoulzadegan, F. (1979). Cycles annuels de la distribution de différentes catégories de particules du seston et essai d'identification des principales poussées phytoplanctoniques dans les eaux néritiques de Villefranche-sur-Mer. J. exp. mar. Biol. Ecol. 38: 41-56

Rassoulzadegan, F. (1982). Temperature dependence of grazing rate, gross growth efficiency and food size range in a pelagic oligotrichous ciliate: Lohmanniella spiralis Leeg., fed on naturally occurring particulate matter. Ann. Inst. océanogr. Paris 58: 177-184

This article was presented by Professor $T$ Fenchel
Rassoulzadegan, F., Etienne, M. (1981). Grazing rate of the tintinnid Stenosemella ventricosa (Clap. \& Lachm.) Jörg. on the spectrum of the naturally occurring particulate matter from a Mediterranean neritic area. Limnol. Oceanogr. 26: 258-270

Rassoulzadegan, F., Gostan, J. (1976). Répartition des ciliés pélagiques dans les eaux de Villefranche-sur-Mer Remarques sur la dispersion du microplancton en mer et à l'intérieur des échantillons dénombrés par la méthode d'Utermöhl. Ann. Inst. océanogr. Paris 52 (2): 175-188

Rassoulzadegan, F., Laval-Peuto, M., Sheldon, R. W. (1988). Partitioning of the food ration of marine ciliates between pico- and nanoplankton. Hydrobiologia 159: 75-88

Rassoulzadegan, F., Sheldon, R. W. (1986). Predator-prey interactions of nanozooplankton and bacteria in an oligotrophic marine environment. Limnol. Oceanogr. 31. 1010-1021

Rivier, A., Brownlee, D. C., Sheldon, R. W., Rassoulzadegan, F. (1985). Growth of microzooplankton: a comparative study of bacterivorous zooflagellates and ciliates. Mar Microb. Food Webs 1: 51-60

Robertson, J. R. (1983). Predation by estuarine zooplankton on tintinnid ciliates. Estuar. coast. Shelf Sci. 16: 27-36

Sheldon, R. W., Nival, P., Rassoulzadegan, F. (1986). An experimental investigation of a flagellate-ciliate-copepod food chain with some observation relevant to the linear biomass hypothesis. Limnol. Oceanogr. 31: 184-188

Sherr, E. B., Sherr, B. F. (1987). High rates of consumption of bacteria by pelagic ciliates. Nature, Lond 325: 710-711

Sherr, E. B., Sherr, B. F., Paffenhöfer, G.-A. (1986). Phagotrophic protozoa as food for metazoa: a 'missing' trophic link in marine pelagic food webs. Mar. Microb. Food Webs 1 (2): $61-80$

Sherr, E. B., Sherr, B. F., Albright, L. J. (1987). Bacteria: link or sink? Science 235: 88-89

Sieburth, J. McN. (1979). Sea microbes. Oxford University Press, New York

Sieburth, J. MCN. (1985). Protozoan bacterivory in pelagic marine waters. In: Hobbie, J. E., Williams P. J. LeB. (eds.) Heterotrophic activity in the sea. Plenum Press, New York, p. $405-444$

Smetacek, V. S. (1981). The annual cycle of protozooplankton in the Kiel Bight. Mar. Biol. 63: 1-11

Stoecker, D. K., Sanders, N. K. (1985). Differential grazing by Acartia tonsa on a dinoflagellate and a tintinnid. J. Plankton Res. 7: 85-100

Stoecker, D. K., Egloff, D. A. (1987). Predation by Acartia tonsa Dana on planktonic ciliates and rotifers. J. exp. mar. Biol. Ecol. 110: 53-68

Stoecker, D. K., Verity, P. G., Michaels, A. E., Davis, L. H. (1987). Feeding by larval and post-larval ctenophores on microzooplankton. J. Plankton Res. 9: 667-683

Throndsen, J. (1978). Preservation and storage. In: Sournia A. (ed.) Phytoplankton manual. Monogr. Oceanogr. 6, UNESCO, p. 69-74

Turner, J. T., Anderson, D. M. (1983). Zooplankton grazing during dinoflagellate blooms in a Cape Cod Embayment, with observation of predation upon tintinnids by copepods. P.S.Z.N.I. Mar. Ecol. 4: 359-374

Manuscript first received: July 3, 1988

Revised version accepted: January 24, 1989 